\title{
Physical activity and sedentary behavior adaptability to COVID-19 social and mobility constraints: a follow-up study in Ilhéus - Bahia/Brazil
}

\section{MARCOS R. T. P. MENUCHI ${ }^{1}$ | ALBERTO B. KRUSCHEWSKYํㅣ | DAVID OHARA ${ }^{1}$ | MARCELO O. HONDA ${ }^{2}$ | MARCO A. AVILA ${ }^{1}$ | PEOLLA P. STEIN ${ }^{3}$ | DUARTE ARAÚJO4}

${ }^{1}$ Health Science Department, Santa Cruz State University, Ilhéus, Brazil.

2 Exact and Technological Sciences Department, Santa Cruz State University, llhéus, Brazil.

${ }^{3}$ South of Bahia Federal University, Itabuna, Brazil.

${ }^{4}$ CIPER, Faculdade de Motricidade Humana, Universidade de Lisboa, Cruz Quebrada, Portugal.

Correspondence to: Marcos Rodrigo Trindade Pinheiro Menuchi. Address: Departamento de Ciências da Saúde - UESC - Ilhéus. Rodovia Jorge Amado, Km 16 , Salobrinho - llhéus - BA - Brasil - 45.662-900. Phone: +55 73 3680-5123.

email: mrtpmenuchi@uesc.br

https://doi.org/10.20338/bjmb.v15i1.212

\begin{abstract}
HIGHLIGHTS
- The quarantine in llhéus changed daily routines and the use of urban space.

- The spaces and routines were adapted to maintain the PA level before the pandemic.

- There was a reduction in the use of leisure spaces, especially in the city center.

- People started to practice PA closer to home.

- There was an increase in total household PA and SB.
\end{abstract}

$\begin{array}{ll}\text { ABBREVIATIONS } \\ \text { COVID-19 } & \text { Coronavirus 2019 } \\ \text { Fiocruz } & \text { Fundação Osvaldo Cruz } \\ \text { IPAQ } & \begin{array}{l}\text { International Physical Activity } \\ \end{array} \\ \text { Questionnaire Long Form } \\ \text { SB } & \text { Sedentary behavior } \\ \text { WHO } & \text { World Health Organization }\end{array}$

PUBLICATION DATA

Received 23112021

Accepted 06012021

Published 01032021
BACKGROUND: The COVID19 Pandemic has impacted human behavior worldwide. Restrictive circulation, working and staying at home, and limitations on outdoor leisure time may have changed people's physical activity level, stimulating sedentary behavior.

AIM: To examine changes in physical activity levels and use of urban space for leisure during quarantine in the municipality of llhéus / BA - Brazil.

METHOD: Thirty-nine (53.8\% of men) residents from llhéus answered an online questionnaire before (prepandemic) and during (post-pandemic) the adoption of social distancing. Physical activity level (IPAQ survey) and places for leisure physical activity were determined by using the GIS technique.

RESULTS: Significant decrease in occupational (-68\%) and transportation (-71\%) time was found. An increase in physical activity at home (152\%) was observed. The average distance from house to leisure physical activity space decreased $74 \%$, and time in sedentary behavior has increased only for men on weekdays $(35 \%)$. CONCLUSION: Even without difference between the total amount of physical activity before and during COVID19, a significant reallocation in time spent in occupational, transportation, household, and space of leisure-time physical activity could indicate demands and adaptations occurred during the study period.

KEYWORDS: Pandemic restrictions | Movement | Inactivity | Urban mobility | Social distancing

\section{INTRODUCTION}

Coronavirus 2019 (COVID-19), caused by the SARS-CoV-2 virus, is an infectious disease of pandemic proportions, ${ }^{1}$ with more than 81 million confirmed cases and 1.8 million deaths worldwide. In June 2020, Brazil reached the mark of 1.8 million infected and more than 70 thousand deaths, being behind only the USA in absolute numbersa. In Brazil, the propagation scenario has grown rapidly and is causing great concern and panic across the world. ${ }^{2}$

The absence of specific preventive or therapeutic medical interventions for COVID-19 infection, along with its rapid transmission rate, as well as the difficulty of accurately documenting transmission and contamination numbers, has led the WHO to

a data collected on 12.27.20 in: https://www.who.int/emergencies/diseases/novel-coronavirus2019?gclid=EAlalQobChMlyfv|xcPP6gIVkcDICh3aXAcmEAAYASAAEgLXsvD BwE 
recommend individuals to stay at home to avoid social interactions and curb the spread of the disease, thereby reducing pressure on health systems worldwide. ${ }^{3}$ Despite being effective in controlling infections, this strategy has potential clinical and behavioral repercussions ${ }^{4}$ which, depending on the duration, can generate physical and mental stress capable of affecting the immune system. ${ }^{5}$ One of the repercussions that have been projected is that home isolation will result in a profound decrease in levels of moderate and vigorous physical activity (PA), as well as an increase in sedentary behavior (SB). ${ }^{5}$

The scientific literature widely describes the positive role of exercise and PA in improving overall health, with positive effects on the cardiovascular and respiratory systems, immune function and antiviral defense, and benefits to metabolic, bone, and muscle disorders, joint pathologies, and neurodegenerative diseases. ${ }^{5}$ Faced with these benefits, scientists are concerned about the impact of urban mobility because we do not yet know what lasting effects the COVID-19 pandemic will have on behavior patterns when life begins to return to normal. ${ }^{6}$

Although the real impact of worldwide isolation on PA levels is still uncertain and unknown, the American company Fitbit, Inc. (fitness area) recently published PA data for 30 million users, demonstrating a substantial reduction (from $7 \%$ to $38 \%$ ) in almost all countries during the last week of March 2020, compared to the same period last year. ${ }^{7}$ This preliminary evidence suggests that quarantine can cause a substantial decline in PA levels, similar to other confined conditions such as incarceration in prison units ${ }^{8}$ and natural disasters. ${ }^{9}$ Some authors even believe two pandemics are occurring at the same time, the COVID-19, improving the physical inactivity, and sedentary behavior (SB) pandemic, with the suspension of the possibility to be physically active (rehabilitation of chronic diseases, school-based physical education, fitness centers, and public parks). ${ }^{6}$ Sustained physical inactivity and SB are typically associated with physical and mental health problems and an increased risk of mortality. ${ }^{10}$ Some studies have shown that sitting or reclining position for 3 to 6 hours is already sufficient to cause cardiovascular function deterioration. ${ }^{11}$

Given the evidence, achieving minimum PA levels (i.e., 150 min of moderate to vigorous $\mathrm{PA}, 75 \mathrm{~min} /$ week of vigorous $\mathrm{PA}$, or a combination of both) and reducing SB in times of social isolation becomes fundamental. With the necessary closure of gyms, sports centers, and parks (social distance measures), maintaining PA has become challenging. For example, Ammar et al. ${ }^{12}$ found that social isolation had a negative impact with a decrease on the level of PA (mild, moderate, vigorous, and total) and on daily SB (an increase from 5 to $8 \mathrm{~h}$ ), along with food losses and alcohol consumption. Cheval et al. ${ }^{13}$ found a decrease in vigorous PA and an increase in SB in the leisure domain. Similar results have been seen in adolescents in southern Croatia. ${ }^{14}$ In Italy, Europe's first epicenter, Maugeri et al. ${ }^{15}$ found a decrease in PA levels at all intensities, especially in men. Finally, a study carried out in $\mathrm{Canada}^{16}$ did not show a specific trend, in which both an increase in PA (mainly in the active population) and a decrease (mainly in the inactive one) were observed.

In Brazil, recent studies have shown that social interaction is important for maintaining PA levels in adolescents. Werneck et al. ${ }^{17}$ found that high PA and low SB levels are associated with low social isolation. In another study, Pinto et al. ${ }^{18}$ found that physically inactive adolescents that do not participate in physical education classes feel more alone and isolated. Together these results confirm previous studies ${ }^{19}$ that 
demonstrate the importance of social interaction in healthy behavior. However, specific studies regarding the impacts of isolation and social distance on the PA behavior of Brazilians are still scarce. Barone et al. ${ }^{20}$ collected information from 1701 Brazilian adults through a questionnaire. $95.1 \%$ of respondents reduced their frequency of going outside of their homes. Similarly, the study by Fundação Osvaldo Cruz (Fiocruz) ${ }^{b}$ registered an increase of $62 \%$ of the physically inactive population. Among the people who did PA threefour days a week, $46 \%$ stopped, and among those who performed five days or more a week, 33\% stopped during the pandemic. In total, before the pandemic, 30\% met WHO recommendations, and during the pandemic, the percentage was only $13 \%$.

Considering the potential challenges to mitigate the spread of COVID-19 and its effects on urban mobility and public health, the present prospective study aimed to examine changes in PA levels and use of urban space for leisure during quarantine in the municipality of Ilhéus/BA - Brazil. We hypothesized a reduction in both physical activity levels and use of urban leisure spaces due to quarantine. Together, both information allowed to describe PA and SB adaptability to Covid-19 social and mobility constraints in Ilhéus - Bahia/Brazil. The restrictions imposed in the municipality can have indirect deleterious effects on the pandemic on issues that affect the health of the population. Being able to measure some of these effects justifies the present study.

\section{METHODS}

\section{Study Location}

This study was conducted in llhéus, a seaside town located in the State of Bahia, Brazil. According to the 2018 IBGE census ${ }^{c}$, Ilhéus has an estimated population of 164.844 thousand inhabitants, a population density of $104.67 / \mathrm{km}^{2}$, and IDHM (municipal human development index) of 0.690 .

\section{Participants}

City residents aged 18 years or older were invited to participate in this study. The pre-COVID19 pandemic data collection (study's baseline) was carried out between November and December 2019, and the During COVID19 pandemic collection between June and July 2020 (Figure 1). This study started as part of another investigation ("Movellhéus: connecting experience, behavior and urban space"). All participants were informed about the objectives, risks, and benefits of the study to agree to the Consent Terms (online format). The original study was approved by the Human Research Ethics Committee of the State University of Santa Cruz (CAAE: 02273118.8.0000.5526), with procedures following the Helsinki Declaration and Ethical guidelines of the Brazilian authorities.

Participants were recruited through snowball sampling using social media, stimulated people to the Movellhéus platform ${ }^{d}$. Thus, the sample of participants was random and uncontrolled. A total of 114 participants fully completed the pre-pandemic collection, and all of these were contacted by email to answer the second collection period.

${ }^{\mathrm{b}}$ Available in: https://convid.fiocruz.br/index.php?pag=atividade_fisica

c Available in: https://cidades.ibge.gov.br/brasil/ba/ilheus/panorama

d Movellhéus platform link: http://moveilheus.uesc.br/ 
As the page was not restricted to pre-pandemic participants, a total of 124 participants fully completed the second questionnaire. Out of these, 39 were eligible for the follow-up study. Participants who did not complete the questionnaire, changed their address in the period, or who changed cities during the pandemic were excluded.
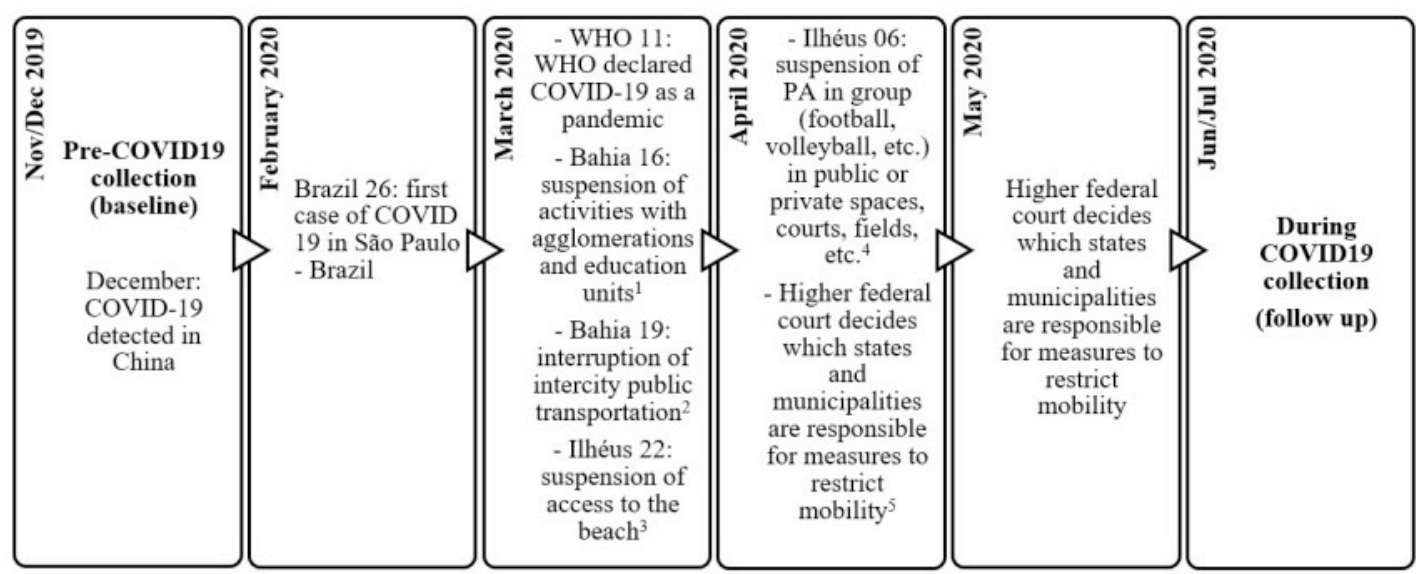

${ }^{1}$ Decree no 19.529 [http://www.legislabahia.ba.gov.br/index.php/documentos/decreto-no-19529-de-16-de-marco-de-2020] 2Decree $n^{0} 19.550$ [http://www.legislabahia.ba.gov.br/index.php/documentos/decreto-no-19550-de-19-de-marco-de-2020] ${ }^{3}$ Decree $n^{0} 020$ [https://www.llheus.ba.gov.br/abrir_arquivo.aspx?cdLocal=12\&arquivo=\%7BBC524B1B-DD56-2BDE-BBCABB4B08CE55C0\%7D.pdf]

${ }^{4}$ Decree $n^{0} 024$

[https://www.ilheus.ba.gov.br/abrir_arquivo.aspx/Legislacao_Municipal_COVID_19_24_2020?cdLocal=5\&arquivo=\%7B4D46A 01E-BB3C-6C81-B8BB-CCB6B1B2D111\%7D.pdf]

Figure 1. Study design, time frames, indicators, and government decrees related to the COVID-19 pandemic for the study period.

\section{Procedures}

The "Movellheus" platform was carried out in the first half of 2019, based on the Finnish SoftGIS methodology (Brown \& Kyttä) ${ }^{21}$ customized for the experiment in llhéus. The "Movellheus" page has an interactive map, in which users must answer questions about punctuation points (pins) on the online map. This allowed the collection of information about PA behavior combined with the locations identified on the map.

The International Physical Activity Questionnaire Long Form (IPAQ) was used to measure PA intensity, duration, and frequency over the previous seven days. The scoring protocol and participants' self-reported data generate a weekly energy expenditure (http://www.ipaq.ki.se). The IPAQ Brazilian version was shown to have good content validity and test-retest reliability. ${ }^{22}$

\section{Data analysis}

Participants' characteristics are presented as mean and SD for continuous variables and frequency and percentages for categorical variables. We used paired t-tests to evaluate the significance of changes from pre restrictive actions to lockdown actions. Effect size (Cohen's $d$ ) was calculated to determine the magnitude of the change and was interpreted using the following criteria: 0.2 (small), 0.5 (moderate), and 0.8 (large). ${ }^{23} \mathrm{All}$ statistical analyses were computed by SPSS-20.0 software (SPSS Inc., Chicago, IL, USA), and significance was set at $5 \%$. 
Georeferenced data were treated statistically with using GIS technology (QGIS3.14.1 software [http://www.qgis.org/]). The SPSS software was used to create a database in which each respondent is a basic unit of analysis. Results are presented both quantitatively (descriptive statistics) and qualitatively (heat mapping). These strategies allowed to describe the distribution and spatial patterns of the variables. For this identification, the data were analyzed using spatial aggregation of points in two dimensions (latitude and longitude) to create heat maps that represent areas of concentration.

We examined the distribution of the PA leisure domain as a function of distance from the domicile. The shortest path between each participant's place of residence and their directions on the map was found using the Network Analyst toolbox of QGIS 3.14.1. Mean distances were calculated from the domicile to each type of mapped location, and a t-test model was used to assess whether the mean distances from the domicile varied by confinement.

\section{RESULTS}

\section{Sample description}

Table 1 lists participant demographics split based on sex. Participants were majority men (53.8\%) aged between $18-49$ years $(89.8 \%)$ and postgraduate $(74.3 \%)$. Regarding household income, there is a greater distribution, with men presenting higher salaries than women.

Table 1 - Sample characteristics $n$ (percentage).

\begin{tabular}{lccc} 
& All (39) & Men (21) & Women (18) \\
\hline Age (years) & & & \\
$18-30$ & $8(18)$ & $5(19)$ & $3(16.8)$ \\
$31-39$ & $10(35.9)$ & $3(33.3)$ & $7(38.9)$ \\
$40-49$ & $14(35.9)$ & $8(38.1)$ & $6(33.3)$ \\
$\geq 50$ & $7(10.2)$ & $5(9.6)$ & $2(11)$ \\
& & & \\
Education & & & \\
Secondary & $4(10.3)$ & $3(9.5)$ & $1(11.1)$ \\
Undergraduate & $6(15.4)$ & $4(23.8)$ & $2(5.6)$ \\
Postgraduate & $29(74.3)$ & $14(66.7)$ & $15(83.3)$ \\
& & & \\
Household Income (minimum & & & \\
wage) & & $2(14.3)$ & $2(11.1)$ \\
$<1$ & $4(12.8)$ & $4(19)$ & $7(33.3)$ \\
$1-3$ & $11(25.7)$ & $3(14.3)$ & $2(11.1)$ \\
$3-5$ & $5(12.8)$ & $5(28.6)$ & $3(27.8)$ \\
$5-10$ & $8(28.2)$ & $7(23.8)$ & $4(16.7)$ \\
$>10$ & $11(20.5)$ & & \\
\hline
\end{tabular}

\section{Physical Activity description}

Responses to the IPAQ recorded in Pre and During COVID19 pandemic are presented in Table 2.

For the occupational PA domain, we observed a decrease of $68 \%(p<0.019, d=$ $0,39)$ for PA total occupation, 69.3\% ( $<<0.013, d=0,42$ for walk PA and $61.1 \%(p<0.039$, 
$d=0,34)$ for moderate PA. In walk PA, men decreased by $63 \%(p<0.039, d=0,48)$. No significant differences were found for all vigorous $\mathrm{PA}$, men moderate and vigorous $\mathrm{PA}$, and for women walk PA, moderate and vigorous.

For the transportation PA domain, we observed a decrease of $71.7 \%(p<0.001, d$ $=0,96$ for total PA transportation, $45.2 \%(p<0.006, d=0,47)$ for walk PA, and $79.8 \%(p<$ $0.001, d=0,85$ ) for car e bus transportation. When stratified by sex, differences were found for men in car/bus using (decrease $79.5 \%$ with $p<0.001, d=0,82$ ) and for women in car/bus using (decrease $79.7 \%$ with $p<0.002, d=0,85$ ) and walk (decrease $83.7 \%$ with $p<0.031, d=0,51$ ). No significant differences were found for all bicycle, men bicycle and walk, and for woman bicycle.

For the household PA domain, the paired t-tests indicated an increase of $152 \%$ ( $p$ $<0.002, d=0,55)$ for PA total household, 79\% $(p<0.015, d=0,41)$ for gardening PA, and $272.2 \%(p<0.000, d=0,62)$ for moderate PA household. When stratified by sex, differences were found for men in moderate PA (increase 69.5\% with $p<0.010, d=0,62$ ) and for women in gardening (increase $89.4 \%$ with $p<0.012, d=0,66$, moderate PA (increase $314.8 \%$ with $p<0.017, d=0,62$ ), and total household (increase $202.1 \%$ with $p<$ $0.007, d=0,72$ ). No significant differences were found for all vigorous PA, men gardening and vigorous $\mathrm{PA}$, and for woman in vigorous $\mathrm{PA}$.

For the leisure PA domain and the total of all domains, no significant differences were found for all comparations.

Finally, for sitting time, no significant differences were found for weekdays, but it showed an increase in sitting time for men on weekend days (increase $34.9 \%$ with $p<$ $0.023, d=0,54$ ).

\section{Use of urban space in the leisure domain}

A total of 39 participants mapped one or more spatial locations of leisure activity resulting in 65 mapped points in the Pre-COVID19 pandemic and 51 in the During COVID19 pandemic. The spatial representativeness of participants is shown in figure 2.

The results show that Pre-Covid-19, the leisure places were concentrated in the city center and public leisure places. The average distance leisure spaces/home was 5 ( \pm 6.7) $\mathrm{km}$. On the other hand, during Covid-19, spaces decreased in numbers and dispersed, concentrating mainly on points on the beach or close to urban areas. The average distance leisure spaces/home was $1.3( \pm 2.1) \mathrm{km}$. The paired t-tests indicated a decrease in distance by $74 \%(p=0.004, d=0.65)$. 
P $\mathrm{BJMB}$

Brazilian Journal of Motor Behavior
Special Issue: COVID-19 (coronavirus disease): Impacts on motor behavior

Table 2 - Physical activity and sitting time according to context (Pre-COVID19 Pandemic vs. during COVID19 Pandemic), domain and gender. Values expressed as mean and standard deviation.

\begin{tabular}{|c|c|c|c|c|c|c|c|c|c|}
\hline \multirow{2}{*}{ PA Domains } & \multicolumn{3}{|c|}{ Pre-COVID19 Pandemic } & \multicolumn{3}{|c|}{ During COVID19 Pandemic } & \multicolumn{3}{|c|}{ During - Pre COVID19 } \\
\hline & $\begin{array}{c}\text { All } \\
(n=39)\end{array}$ & Men $(n=21)$ & $\begin{array}{c}\text { Women } \\
(n=18)\end{array}$ & All $(n=39)$ & $\operatorname{Men}(n=21)$ & $\begin{array}{c}\text { Women } \\
(n=18)\end{array}$ & All $(n=39)$ & $\begin{array}{c}\text { Men } \\
(n=21)\end{array}$ & $\begin{array}{c}\text { Women } \\
(n=18)\end{array}$ \\
\hline \multicolumn{10}{|l|}{ Occupational } \\
\hline Walk & $\begin{array}{l}84.6 \pm \\
213.9\end{array}$ & $\begin{array}{c}130.0 \pm \\
273.9\end{array}$ & $\begin{array}{c}31.6 \pm \\
92.3\end{array}$ & $\begin{array}{c}25.8 \pm \\
89.2\end{array}$ & $\begin{array}{c}48.0 \pm \\
118.3\end{array}$ & - & $\begin{array}{l}-58.7 \pm \\
140.3^{\star}\end{array}$ & $\begin{array}{l}-81.9 \pm \\
170.1^{*}\end{array}$ & $\begin{array}{c}-31.6 \pm \\
92.3\end{array}$ \\
\hline Moderate & $\begin{array}{c}95.6 \pm \\
190.7\end{array}$ & $\begin{array}{c}141.9 \pm \\
237.7\end{array}$ & $\begin{array}{c}41.6 \pm \\
95.1\end{array}$ & $\begin{array}{c}37.1 \pm \\
94.2\end{array}$ & $\begin{array}{c}60.4 \pm \\
118.7\end{array}$ & $\begin{array}{l}10 \pm \\
42.4\end{array}$ & $\begin{array}{l}-58.4 \pm \\
171.2^{\star}\end{array}$ & $\begin{array}{l}-81.4 \pm \\
210.9\end{array}$ & $\begin{array}{c}-31.6 \pm \\
108\end{array}$ \\
\hline Vigorous & $\begin{array}{c}41.0 \pm \\
168.2\end{array}$ & $\begin{array}{l}73.3 \pm \\
226.3\end{array}$ & $\begin{array}{l}3.3 \pm \\
14.1\end{array}$ & $\begin{array}{l}7.6 \pm \\
34.2\end{array}$ & $\begin{array}{c}14.2 \pm \\
46.1\end{array}$ & - & $\begin{array}{c}-33.3 \pm \\
137.4\end{array}$ & $\begin{array}{c}-59.0 \pm \\
184.9\end{array}$ & $\begin{array}{c}-3.3 \pm \\
14.1\end{array}$ \\
\hline $\begin{array}{c}\text { Total } \\
\text { occupational }\end{array}$ & $\begin{array}{c}221.2 \pm \\
528.3\end{array}$ & $\begin{array}{c}345.2 \pm \\
688.0\end{array}$ & $\begin{array}{c}76.6 \pm \\
160.9\end{array}$ & $\begin{array}{c}70.7 \pm \\
191.5\end{array}$ & $\begin{array}{c}122.8 \pm \\
249.0\end{array}$ & $\begin{array}{l}10 \pm \\
42.4\end{array}$ & $\begin{array}{l}-150.5 \pm \\
382.3^{*}\end{array}$ & $\begin{array}{c}-222.3 \pm \\
490.9\end{array}$ & $\begin{array}{c}-66.6 \pm \\
171.2\end{array}$ \\
\hline \multicolumn{10}{|l|}{ Transportation } \\
\hline $\begin{array}{l}\text { Car, bus, train, } \\
\text { subway }\end{array}$ & $\begin{array}{l}807.4 \pm \\
720.6\end{array}$ & $\begin{array}{c}782.3 \pm \\
746.2\end{array}$ & $\begin{array}{c}836.6 \pm \\
709.9\end{array}$ & $\begin{array}{c}163.0 \pm \\
296.7\end{array}$ & $\begin{array}{c}157.6 \pm \\
325.4\end{array}$ & $\begin{array}{l}169.4 \pm \\
268.5\end{array}$ & $\begin{array}{l}-644.3 \pm \\
762.1^{* *}\end{array}$ & $\begin{array}{l}-624.7 \pm \\
761.2^{*}\end{array}$ & $\begin{array}{l}-667.2 \pm \\
784.6^{*}\end{array}$ \\
\hline Bicycle & $\begin{array}{l}38.2 \pm \\
127.4\end{array}$ & $\begin{array}{l}56.6 \pm \\
169.7\end{array}$ & $\begin{array}{c}16.6 \pm \\
38.8\end{array}$ & $\begin{array}{c}25.1 \pm \\
96.9\end{array}$ & $\begin{array}{l}35.2 \pm \\
122.1\end{array}$ & $\begin{array}{c}13.3 \pm \\
56.5\end{array}$ & $\begin{array}{c}-13.0 \pm \\
65.7\end{array}$ & $\begin{array}{c}-21.4 \pm \\
71.3\end{array}$ & $\begin{array}{c}-3.3 \pm \\
59\end{array}$ \\
\hline Walk & $\begin{array}{l}190.5 \pm \\
287.4\end{array}$ & $\begin{array}{c}227.6 \pm \\
339.9\end{array}$ & $\begin{array}{c}147.2 \pm \\
212.2\end{array}$ & $\begin{array}{c}104.3 \pm \\
235.1\end{array}$ & $\begin{array}{l}173.3 \pm \\
302.3\end{array}$ & $\begin{array}{c}23.8 \pm \\
57.9\end{array}$ & $\begin{array}{l}-86.1 \pm \\
184.4^{\star}\end{array}$ & $\begin{array}{l}-54.2 \pm \\
142.2\end{array}$ & $\begin{array}{l}-123.3 \pm \\
222.4^{*}\end{array}$ \\
\hline $\begin{array}{c}\text { Total } \\
\text { transportation }\end{array}$ & $\begin{array}{c}1036.1 \pm \\
784.1\end{array}$ & $\begin{array}{l}1066.6 \pm \\
841.6\end{array}$ & $\begin{array}{c}1000.5 \pm \\
733.9\end{array}$ & $\begin{array}{c}292.5 \pm \\
406.7\end{array}$ & $\begin{array}{c}366.1 \pm \\
488.2\end{array}$ & $\begin{array}{c}206.6 \pm \\
273.7\end{array}$ & $\begin{array}{l}-743.5 \pm \\
777.7^{\star *}\end{array}$ & $\begin{array}{l}-700.4 \pm \\
762.4^{\star \star}\end{array}$ & $\begin{array}{l}-793.8 \pm \\
814.5^{*}\end{array}$ \\
\hline \multicolumn{10}{|l|}{ Household } \\
\hline Gardening & $\begin{array}{c}178.9 \pm \\
178.6\end{array}$ & $\begin{array}{c}201.4 \pm \\
193.0\end{array}$ & $\begin{array}{c}152.7 \pm \\
161.7\end{array}$ & $\begin{array}{c}347.1 \pm \\
411.8\end{array}$ & $\begin{array}{c}341.4 \pm \\
494.2\end{array}$ & $\begin{array}{c}353.8 \pm \\
302.8\end{array}$ & $\begin{array}{l}168.2 \pm \\
412.3^{*}\end{array}$ & $\begin{array}{c}140.0 \pm \\
492.6\end{array}$ & $\begin{array}{l}201.7 \pm \\
304.1^{*}\end{array}$ \\
\hline Moderate & $\begin{array}{c}124.8 \pm \\
157.4\end{array}$ & $\begin{array}{c}122.8 \pm \\
136.5\end{array}$ & $\begin{array}{c}127.2 \pm \\
182.9\end{array}$ & $\begin{array}{c}464.8 \pm \\
561.2\end{array}$ & $\begin{array}{c}410.9 \pm \\
487.5\end{array}$ & $\begin{array}{c}527.7 \pm \\
645.5\end{array}$ & $\begin{array}{l}340.0 \pm \\
549.6^{\star \star}\end{array}$ & $\begin{array}{l}288.0 \pm \\
466.7^{*}\end{array}$ & $\begin{array}{l}400.5 \pm \\
641.6^{*}\end{array}$ \\
\hline Vigorous & $\begin{array}{c}63.0 \pm \\
142.4\end{array}$ & $\begin{array}{c}90.0 \pm \\
184.3\end{array}$ & $\begin{array}{c}31.6 \pm \\
58.6\end{array}$ & $\begin{array}{c}113.0 \pm \\
258.3\end{array}$ & $\begin{array}{c}158.5 \pm \\
329.3\end{array}$ & $\begin{array}{c}60 \pm \\
126.8\end{array}$ & $\begin{array}{c}50.0 \pm \\
259.3\end{array}$ & $\begin{array}{l}68.5 \pm \\
329.2\end{array}$ & $\begin{array}{c}28.3 \pm \\
147.8\end{array}$ \\
\hline Total household & $\begin{array}{c}366.9 \pm \\
375.0\end{array}$ & $\begin{array}{c}414.2 \pm \\
417.3\end{array}$ & $\begin{array}{c}311.6 \pm \\
321.6\end{array}$ & $\begin{array}{r}925.1 \pm \\
1061.2\end{array}$ & $\begin{array}{l}910.9 \pm \\
1199.1\end{array}$ & $\begin{array}{l}941.6 \pm \\
908.4\end{array}$ & $\begin{array}{l}558.2 \pm \\
1022.4^{*}\end{array}$ & $\begin{array}{c}496.6 \pm \\
1153.8\end{array}$ & $\begin{array}{l}630.0 \pm \\
872.0^{*}\end{array}$ \\
\hline \multicolumn{10}{|l|}{ Leisure time } \\
\hline Walk & $\begin{array}{c}112.8 \pm \\
156.7\end{array}$ & $\begin{array}{c}159.5 \pm \\
192.2\end{array}$ & $\begin{array}{c}58.3 \pm \\
74.8\end{array}$ & $\begin{array}{c}136.4 \pm \\
182.2\end{array}$ & $\begin{array}{c}166.6 \pm \\
170.2\end{array}$ & $\begin{array}{c}101.1 \pm \\
194\end{array}$ & $\begin{array}{c}23.5 \pm \\
185.4\end{array}$ & $\begin{array}{l}7.1 \pm \\
184.3\end{array}$ & $\begin{array}{r}42.7 \pm \\
190.1\end{array}$ \\
\hline Moderate & $\begin{array}{c}137.6 \pm \\
239.4\end{array}$ & $\begin{array}{c}203.3 \pm \\
291.9\end{array}$ & $\begin{array}{l}61.1 \pm \\
127.7\end{array}$ & $\begin{array}{c}104.8 \pm \\
217.8\end{array}$ & $\begin{array}{c}153.3 \pm \\
245.9\end{array}$ & $\begin{array}{c}48.3 \pm \\
169.1\end{array}$ & $\begin{array}{l}-32.8 \pm \\
226.5\end{array}$ & $\begin{array}{c}-50.0 \pm \\
239.8\end{array}$ & $\begin{array}{c}-12.7 \pm \\
215\end{array}$ \\
\hline Vigorous & $\begin{array}{c}114.8 \pm \\
170.2\end{array}$ & $\begin{array}{c}141.9 \pm \\
203.5\end{array}$ & $\begin{array}{c}83.3 \pm \\
118.6\end{array}$ & $\begin{array}{c}89.2 \pm \\
164.4\end{array}$ & $\begin{array}{c}65.7 \pm \\
151.9\end{array}$ & $\begin{array}{c}116.6 \pm \\
178.2\end{array}$ & $\begin{array}{c}-25.6 \pm \\
228.7\end{array}$ & $\begin{array}{c}-76.1 \pm \\
235.0\end{array}$ & $\begin{array}{l}33.3 \pm \\
212.4\end{array}$ \\
\hline $\begin{array}{l}\text { Total leisure } \\
\text { time }\end{array}$ & $\begin{array}{c}365.3 \pm \\
438.9\end{array}$ & $\begin{array}{l}504.7 \pm \\
511.5\end{array}$ & $\begin{array}{c}202.7 \pm \\
266.2\end{array}$ & $\begin{array}{l}330.5 \pm \\
461.6\end{array}$ & $\begin{array}{l}385.7 \pm \\
489.7\end{array}$ & $\begin{array}{c}266.1 \pm \\
431.3\end{array}$ & $\begin{array}{c}-34.8 \pm \\
453.2\end{array}$ & $\begin{array}{c}-119.0 \pm \\
410.9\end{array}$ & $\begin{array}{l}63.3 \pm \\
491.5\end{array}$ \\
\hline $\begin{array}{l}\text { Total All } \\
\text { domains }\end{array}$ & $\begin{array}{c}1989.7 \pm \\
1452.9\end{array}$ & $\begin{array}{c}2330.9 \pm \\
1757.2\end{array}$ & $\begin{array}{c}1592.6 \pm \\
879.9\end{array}$ & $\begin{array}{c}1618.9 \pm \\
1507.5\end{array}$ & $\begin{array}{c}1785.7 \pm \\
1767.5\end{array}$ & $\begin{array}{c}1424.4 \pm \\
1153.1\end{array}$ & $\begin{array}{c}-370.7 \pm \\
1356.9\end{array}$ & $\begin{array}{c}-545.2 \pm \\
1532.2\end{array}$ & $\begin{array}{c}-167.2 \pm \\
1127.7\end{array}$ \\
\hline \multicolumn{10}{|l|}{ Sitting time } \\
\hline Weekday & $\begin{array}{c}369.4 \pm \\
190.0\end{array}$ & $\begin{array}{c}327.6 \pm \\
181.6\end{array}$ & $\begin{array}{c}418.3 \pm \\
192.9\end{array}$ & $\begin{array}{c}421.0 \pm \\
224.3\end{array}$ & $\begin{array}{c}429.0 \pm \\
222.1\end{array}$ & $\begin{array}{c}411.6 \pm \\
233\end{array}$ & $\begin{array}{c}51.5 \pm \\
249\end{array}$ & $\begin{array}{c}101.4 \pm \\
224.9\end{array}$ & $\begin{array}{l}-6.6 \pm \\
269.1\end{array}$ \\
\hline Weekend day & $\begin{array}{c}293.8 \pm \\
207.0\end{array}$ & $\begin{array}{c}249.5 \pm \\
190.9\end{array}$ & $\begin{array}{c}345.5 \pm \\
218.2\end{array}$ & $\begin{array}{c}352.3 \pm \\
250.1\end{array}$ & $\begin{array}{c}336.6 \pm \\
214.8\end{array}$ & $\begin{array}{c}370.5 \pm \\
291.3\end{array}$ & $\begin{array}{c}58.4 \pm \\
207.4\end{array}$ & $\begin{array}{l}87.1 \pm \\
162.3^{*}\end{array}$ & $\begin{array}{l}25 \pm \\
251\end{array}$ \\
\hline
\end{tabular}



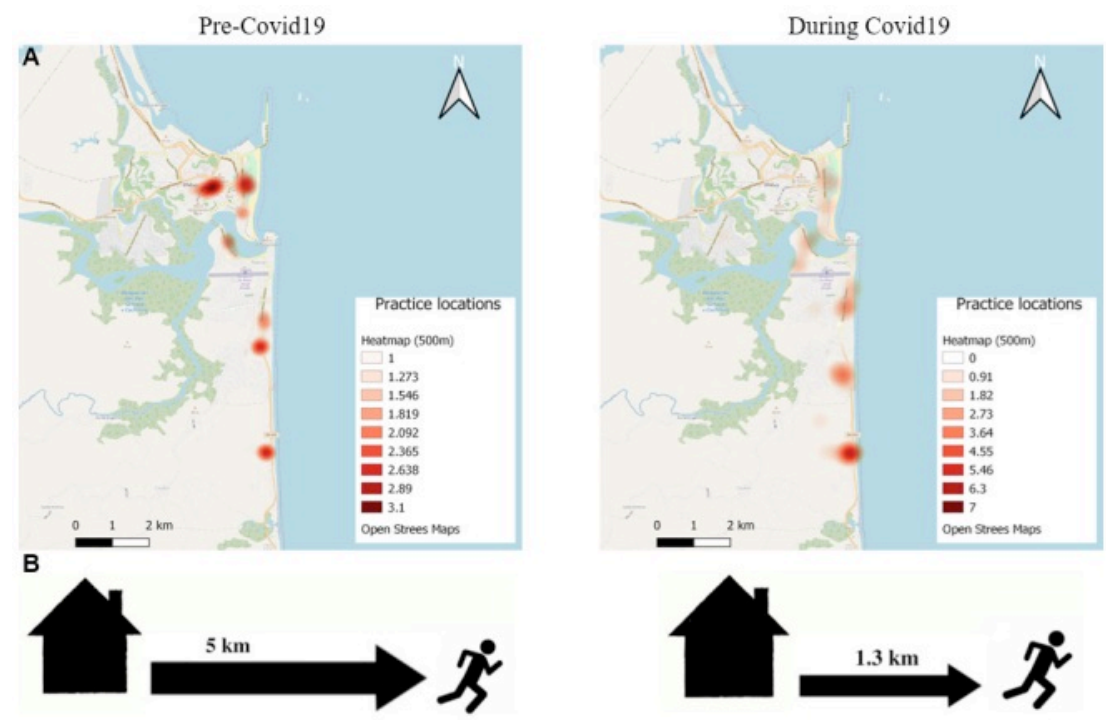

Figure 2. A: Distribution of mapped points (leisure practice locations) in llhéus pre-Covid-19 and during Covid-19. The legend indicates the number of points indicated in clusters of $500 \mathrm{~m}$. B: drawing representing the average distance between the place of leisure and the house.

\section{DISCUSSION}

This study aimed to examine changes in PA levels and use of urban space for leisure during quarantine in the municipality of llhéus / BA - Brazil. Although there was no significant difference in the total time spent on physical activities, the results partially confirm our hypothesis showing a reduction in occupational and transport physical activity and an increase in domestic physical activities. We also see changes in sitting time on weekends for men only. On the other hand, there were no changes in the leisure domains but decreased the distance from the house to urban leisure spaces during the confinement period.

In line with the results presented by Fitbit, Inc., ${ }^{7}$ where global daily commuting decreased significantly in March, the present study measures of mobility restrictions appear to have been effective due to the reduction of PA in the occupational and transportation domains as well as in the urban spaces used for leisure. The worldwide spread of COVID-19 infection has led the Brazilian government to apply unprecedented containment measures. In the State of Bahia, the governor decreed on 03/16/2020 the suspension of mass gatherings and school activities. In llhéus, the city government issued the first restriction measure on 03/22/2020, prohibiting the use of beaches and nonessential stores and services. These measures constrained PA's practice, especially in places with a greater flow of people, showing a significant reduction in occupied spaces for leisure, especially in the city center (see Figure 2A). The quarantine forced the population to social distancing and self-isolation. Preventive measures included sports-related activities, especially in groups, except walking and running outdoors. Therefore, training and PA at home and around remained the only possibility for staying active during the Covid-19 pandemic. Interestingly, the modification of leisure places did not alter the PA in the leisure domain. For this group, the spaces and routines were adapted to maintain PA. 
The results of the distance from home to leisure places showed that people started to practice PA closer to home, probably using the neighborhood spaces. Studies investigating the use of urban space for PA indicate that people seek places closer to home for physical exercise, dog walking, walking, and running. ${ }^{24}$ In addition, human-nature interactions have been presented as important for promoting and sustaining wellbeing and health benefits, ${ }^{25}$ which may explain the search for PA on the beach near the home, considering that walking and running activities are allowed or less visible in these places.

In disagreement with most of the results presented in other countries, ${ }^{12-16}$, the present study participants managed to maintain the PA level presented in the Pre-COVID period. Our results showed that the reduction in PA levels in the occupational and transport domains was somehow compensated for household domain PA. We observed an increase in total household PA moderate activities (both sexes) and gardening (only for women) due to a radical change in schedules and daily habits. People who stay at home spend much more time on low-intensity activities, such as household tasks (cooking, washing the dishes, or gardening)..$^{15}$ Another evident factor is the increased demand for physical activities at home. According to Oliveira Neto, ${ }^{26}$ using Google Trends, the search terms "training in home" and "Covid-19" have grown exponentially and are strongly correlated. The use of home exercise programs becomes relevant to mitigate the deleterious effects of increased inactivity, but an eventual increase in the sessions' frequency and intensity may require professional guidance. Technological advances in recent years have driven the emergence of many tools, such as PA trackers and applications for watches and smartphones, which can help improving the provision of supervised PA interventions. These advances may also be relevant to expand the scope of such interventions to populations unable to participate in face-to-face counseling. However, the lack of standardization of home exercise intervention for different populations and physical fitness and cardiovascular conditions remains a matter of concern that must be addressed in the coming years. ${ }^{2,26}$ The concern is even greater if we consider the importance of the immune system for the moment and the harmful effects that an inadequate dose of exercise, combined with aspects such as a break in the circadian rhythm, poor diet or psychological stress, conditions that are not uncommon in times of crisis. ${ }^{5}$

The differences by sex are in accordance with Sekulic et al. ${ }^{14}$, Maugeri et al. ${ }^{15}$. According to $\mathrm{Li}$ et al. ${ }^{27}$, showing that men practice PA mainly for social and competitive reasons. In addition, they prefer to play sports, outdoors and/or in private places, such as gyms and clubs. Women are more likely to exercise at home, practicing aerobic exercise, dancing, yoga, pilates, or functional circuits.

For a sitting time, despite the differences for men on weekends, what calls attention are the high values in the baseline, $6 \mathrm{~h}$ of sitting time on weekdays, and almost $5 \mathrm{~h}$ on weekends, with women being a little more sedentary than men. It is important to highlight that this threshold increases the risk of disease and mortality. ${ }^{28}$ The increased risk was observed for 6-8 hours a day in a sitting position and 3-4 hours a day watching television. A high level of physical inactivity was also associated with a worse state of mental health in different age groups. ${ }^{28}$

Homestay and homeworking likely increase sitting time, specifically time in front of the TV, mobile phone, and computer. Regular interruptions are therefore suggested. ${ }^{29}$ Jakobsson et al. ${ }^{29}$ emphasize the importance of interrupting prolonged sitting time, with benefits for metabolic health. For the authors, regular interruptions of 3-min of light- 
intensity activities during 210 min of sedentary time can diminish the glycemic response following a high-energy meal, valuable for glycemic control.

\section{Strengths and Limitations}

One of the limitations of this study is the use of self-report subjective measures, which can generate a bias of over or underestimating PA. However, IPAQ questionnaires have provided a reliable approximation of PA at the population level, and their validity has been confirmed in different studies, including the Brazilian version. ${ }^{22}$

Another limitation was the small sample size. This was due to the difficulty of following the participants in the two data collection periods. When the pandemic arrived in Brazil, the containment included authorization only for essential work. People lost their jobs or started to work remotely, becoming possible to move to family members' homes. This movement can be seen in Bezerra et al. ${ }^{30}$, who found an increase in the national average of people per household during isolation.

Finally, we highlight that the sample set may not be representative of the profile of Ilhéus residents. Studies using an instrument with questionnaires and maps on the Internet have shown younger respondents' profile, with higher education and higher socioeconomic status. This can generate bias in understanding the city's behavior, as llhéus is a diverse municipality with contrasts and unequal living conditions. Thus, due to the differences of comfort and structure that the population lives, it is not about being isolated or not, but also in the conditions of that isolation. ${ }^{30}$

\section{CONCLUSION AND FUTURE PERSPECTIVES}

Given the limitations inherent in this follow-up study, our results, for the first time in the literature, have shown that quarantine in llhéus changed daily routines and the use of urban space, inducing adaptations in the residents' PA behavior in order to seek to maintain the level of PA before the pandemic. The results reported in this paper should be utilized for further research and development in public health promotion during the COVID19 pandemic. Given the spread of COVID-19, stay at home is a fundamental step to halt the pandemic. However, motivating people to stand up can be the first step of health promotion against sedentary behavior.

Our results also suggest that people who live in neighborhoods with fewer options and infrastructure will experience greater impacts and difficulties in maintaining an active life. This directs efforts so that managers also observe urban space as priority actions, considering the uncertainty of finalizing restrictions imposed by COVID-19. With these observations, strategies such as 'move more and sit less during the day' can be promoted as safe and accessible options to mitigate the deleterious effects of inactivity imposed during self-isolation.

\section{REFERENCES}

1. World Health Organization. Statement on the Second Meeting of the International Health Regulations (2005) Emergency Committee Regarding the Outbreak of Novel Coronavirus (2019-nCoV). Available at: https://www.who.int/news-room/detail/30-01-2020-statement- 
on-the-second-meeting-of-the-international-health-regulations-(2005)-emergencycommittee-regarding-the-outbreak-of-novel-coronavirus-(2019-ncov) [accessed 21.06.2020].

2. Chen P, Mao L, Nassis GP, Harmer P, Ainsworth BE, Li F. Coronavirus disease (COVID19): The need to maintain regular physical activity while taking precautions. J Sport Health Sci. 2020; 9: 103-4. 10.1016/j.jshs.2020.02.001

3. Cheng C, Barceló J, Hartnett AS, Kubinec R, Messerschmidt L. COVID-19 Government Response Event Dataset (CoronaNet v.1.0). Nat hum Behav. 2020; 4: 756-86. 10.1038/s41562-020-0909-7

4. Brooks SK, Webster RK, Smith LE, Woodland L, Wessely S, Greenberg N, et al. The psychological impact of quarantine and how to reduce it: rapid review of the evidence. Lancet. 2020; 395: 912-20. 10.1016/S0140-6736(20)30460-8

5. Woods J, Hutchinson NT, Powers SK, Roberts WO, Gomez-Cabrera M, Radak Z, et al. The COVID-19 Pandemic and Physical Activity. Sports Med. Health Sci. 2020; 10.1016/j.smhs.2020.05.006

6. Hall G, Laddu DR, Phillips SA, Lavie CJ, Arena R. A tale of two pandemics: How will COVID-19 and global trends in physical inactivity and sedentary behavior affect one another? Prog Cardiovasc Dis. 2020. 10.1016/j.pcad.2020.04.005

7. Fitbit, Inc. The Impact of Coronavirus on Global Activity. Avaliable at: https://blog.fitbit.com/covid-19-global-activity/. [acessed 21.06.2020].

8. Arries EJ, Maposa S. Cardiovascular risk factors among prisoners: an integrative review. J Forensic Nurs. 2013; 9: 52-64. 10.1097/jfn.0b013e31827a59ef

9. Okazaki K, Suzuki K, Sakamoto Y, Sasaki K. Physical activity and sedentary behavior among children and adolescents living in an area affected by the 2011 Great East Japan earthquake and tsunami for 3 years. Prev Med Rep. 2015; 2: 720-4. 10.1016/j.pmedr.2015.08.010

10. Booth FW, Roberts CK, Thyfault JP, Ruegsegger GN, Toedebusch RG. Role of inactivity in chronic diseases: evolutionary insight and pathophysiological mechanisms. Physiol Rev. 2017; 97: 1351-402. 10.1152/physrev.00019.2016

11. Hadgraft NT, Winkler E, Climie RE, Grace MS, Romero L, Owen N, et al. Effects of sedentary behaviour interventions on biomarkers of cardiometabolic risk in adults: systematic review with meta-analyses. Br J Sports Med. 2020; 04: 1-13. 10.1136/bjsports-2019-101154

12. Ammar A, Brach M, Trabelsi K, Chtourou H, Boukhris O, Masmoudi L, et al. Effects of COVID-19 Home Confinement on Eating Behaviour and Physical Activity: Results of the ECLB-COVID19 International Online Survey. Nutrients. 2020; 12: 1-13. 10.3390/nu12061583

13. Cheval B, Sivaramakrishnan H, Maltagliati S, Fessler L, Forestier C, Sarrazin P, et al. Relationships Between Changes in Self-Reported Physical Activity and Sedentary 
Behaviours and Health During the Coronavirus (COVID-19) Pandemic in France and Switzerland. J Sports Sci. 2020. 10.1080/02640414.2020.1841396

14. Sekulic D, Blazevic M, Gilic B, Kvesic I, Zenic N. Prospective Analysis of Levels and Correlates of Physical Activity during COVID-19 Pandemic and Imposed Rules of Social Distancing; Gender Specific Study among Adolescents from Southern Croatia.

Sustainability. 2020; 12: 1-13. 10.3390/su12104072

15. Maugeri G, Castrogiovanni P, Battaglia G, Pippi R, D'Agata V, Palma A, et al. The impact of physical activity on psychological health during Covid-19 pandemic in Italy. Heliyon. 2020; 6: 3-8. 10.1016/j.heliyon.2020.e04315

16. Lesser IA, Nienhuis CP. The impact of COVID-19 on physical activity behavior and wellbeing of Canadians. Int J Environ Res Publ Health. 2020; 17: 3899. 10.3390/ijerph17113899

17. Werneck AO, Collings PJ, Barboza LL, Stubbs B, Silva DR. Associations of sedentary behaviors and physical activity with social isolation in 100,839 school students: The Brazilian Scholar Health Survey. Gen Hosp Psychiatry. 2019; 59: 7-13. 10.1016/j.genhosppsych.2019.04.010

18. Pinto AA, Oppong Asante K, Puga Barbosa R, Nahas MV, Dias DT, Pelegrini A. Association between loneliness, physical activity, and participation in physical education among adolescents in Amazonas, Brazil. J Health Psychol. 2019; 7: 1-9. 10.1177/1359105319833741

19. Montgomery SC, Donnelly M, Bhatnagar P, Carlin A, Kee F, Hunter RF. Peer social network processes and adolescent health behaviors: a systematic review. Prev Med. 2020; 130: 1-19. 10.1016/j.ypmed.2019.105900

20. Barone MTU, Harnik SB, de Luca PV, de Souza Lima BL, Wieselberg RJP, Ngongo B, et al. The Impact of COVID-19 on People with Diabetes in Brazil. Diabetes Res Clin Pract. 2020; 166: 1-9. 10.1016/j.diabres.2020.108304

21. Brown $G$, Kytta M. Key issues and research priorities for public participation GIS (PPGIS): A synthesis based on empirical research. Applied Geography. 2014; 46: $122-36$. 10.1016/j.apgeog.2013.11.004

22. Matsudo S, Araújo T, Matsudo V, Andrade D, Andrade E, Oliveira LC, et al. Questionário internacional de atividade física (IPAQ): estudo de validade e reprodutibilidade no brasil. Rev Bras Ativ Fis Saúde. 2001; 6: 5-18. 10.12820/rbafs.v.6n2p5-18

23. Cohen J. Statistical Power Analysis for the Behavioral Sciences. New York: Routledge Academic; 1988.

24. Brown G, Rhodes J, Dade M. An evaluation of participatory mapping methods to assess urban park benefits. Landsc Urban Plan. 2018; 178: 18-31. 10.1016/j.landurbplan.2018.05.018

25. Brymer E, Araújo D, Davids K, Pepping G-J. Conceptualizing the Human Health Outcomes of Acting in Natural Environments: An Ecological Perspective. Front Psychol. 2020; 11: 1-6. 10.3389/fpsyg.2020.01362 
26. Oliveira Neto L, Elsangedy HM, Tavares VDDO, Teixeira CVLS, Behm DG, Da Silva-Grigoletto ME. \#TraininglnHome - Home-based training during COVID-19 (SARS-COV2) pandemic: physical exercise and behavior-based approach. Rev Bras Fisiol Exerc. 2020; 19: 9-19. 10.33233/rbfe.v19i2.4006

27. Li W, Procter-Gray E, Churchill L, Crouter SE, Kane K, Cheng J, et al. Gender and age differences in levels, types and locations of physical activity among older adults living in cardependent neighborhoods. J Frailty Aging. 2017; 6: 129-35. 10.14283/jfa.2017.15

28. Grgic J, Dumuid D, Bengoechea EG, Shrestha N, Bauman A, Olds T, et al. Health outcomes associated with reallocations of time between sleep, sedentary behaviour, and physical activity: a systematic scoping review of isotemporal substitution studies. Int J Behav Nutr Phys Act. 2018; 15: 69. 10.1186/s12966-018-0691-3

29. Jakobsson J, Malm C, Furberg M, Ekelund U, Svensson M. Physical Activity During the Coronavirus (COVID-19) Pandemic: Prevention of a Decline in Metabolic and Immunological Functions. Front Sports Act Living. 2020; 2: 1-4. 10.3389/fspor.2020.00057

30. Bezerra ACV, Silva CEM, Soares FRG, Silva JAM. Factors associated with people's behavior in social isolation during the COVID-19 pandemic. Cien Saude Colet. 2020; 25: 2411-21. 10.1590/1413-81232020256.1.10792020

\section{ACKNOWLEDGEMENTS}

We would like to thank Johnatas Barbosa and Annya Ourives for their assistance in developing the Movellheus platform. Ricardo Becker, Elvis Barbosa, Paulo Ambrósio, João Lisboa, and the other members of GEPECOM (http://dgp.cnpq.br/dgp/espelhogrupo/31991) for their assistance in participant recruitment and data collection. We also would like to thank Nossa Ilhéus Institute, a coalition dedicated to improving the sustainable city.

Citation: Menuchi MRTP, Kruschewsky AB, Ohara D, Honda MO, Ávila MA, Stein PP, Araújo D. Physical activity and sedentary behaviour adaptability to COVID-19 social and mobility constraints: a follow up study in llhéus -

Bahia/Brazil. BJMB. 2021:15(1): 34-46.

Editors: Dr Fabio Augusto Barbieri - São Paulo State University (UNESP), Bauru, SP, Brazil; Dr José Angelo Barela São Paulo State University (UNESP), Rio Claro, SP, Brazil; Dr Natalia Madalena Rinaldi - Federal University of Espirito Santo (UFES), Vitória, ES, Brazil.

Copyright: @ 2021 Menuchi, Kruschewsky, Ohara, Honda, Ávila, Stein and Araújo and BJMB. This is an open-access article distributed under the terms of the Creative Commons Attribution-Non Commercial-No Derivatives 4.0 International License which permits unrestricted use, distribution, and reproduction in any medium, provided the original author and source are credited.

Funding: This work was supported by the Santa Cruz State University [grant numbers 00220.1600 .1897 ] and by South of Bahia Federal University [grant CFTCI 01/2020].

Competing interests: The authors have declared that no competing interests exist.

DOl: https://doi.org/10.20338/bjmb.v15i1.212 